\title{
The Impact of Global Culture on Javanese Culture in the Craftsmen Society of Earthenware Craft Arts of Pundong, Bantul, Yogyakarta, Indonesia
}

\author{
Timbul Raharjo \\ ${ }^{I}$ (The Master Program of Art Management, the Postgraduate Program/Indonesian Institutes of the \\ Arts/Indonesia)
}

\begin{abstract}
Pundong is craft art centre of Bantul district of the Yogyakarta Indonesia that expors earthenware art products to other countries. An interaction with global culture takes place because of the exporting relationship of the earthenware arts and it results in the modernization in international relationship. A study of the transformation pattern in the cultural sociological theory of Pundong puts the emphasis on both external and internal factors as the transformation element and the component of its formative culture, which are cultural institutions, cultural content and cultural effects. The openness of Pundong society to accept external influence causes cultural shift, especially value system, living pattern and business activity of earthenware art. New pattern develops in Javanese cultural value system in Pundong to adapt to the living pattern they consider as modern. The cultural transformation gets its deep root and influences the behavior of the villagers to win global business competition.
\end{abstract}

Keywords: culture, Javanese, earthenware, craftsmen

\section{Introduction}

Pundong is a sub district area situated south of Yogyakarta City, precisely at Jl. Parangtritis Km 19 Yogyakarta. The majority of Pundong people work as artistic earthenware craftsmen. On May $200690 \%$ of the houses of the local people were seriously damaged by earthquake. Howe ever, they renascent with their earthenware craft artistic products they exported to other countries.

As a result of information and communication globalization, the majority of the craftsmen who are lack of knowledge face increasingly complex problems. They are likely to maintain the existing traditional values they have long embraced and avoid global contact. Meanwhile, a few of them who are responsive to the globalization era and have progressive thought try to adapt to the modernization of the globalization era in their preparation to face global challenge. The craftsmen of the earthenware craft art industry of Pundong are social beings who cannot escape the relationship with other nations and consequently they have to face the globalization, including technology (Murniatmo, 1993/1994: 3). The globalization int its concrete form manifests itself in economic and trade liberalization so that all global economic efforts are directed to respond the globalization era. Even, it has increasingly strong influence. The prior obstacles have been successfully overcome. The earthenware craftsmen society of Pundong considers the globalization as certainty. Though Pundong has not been as good as Kasongan as producer of earthenware craft artistic products, its transformation is clearly observed in the global interaction, especially in their working pattern and their management of the production of the earthenware craft artistic products.

Globalization is a term closely related to increase, relatedness and global interdependency of nations through trade, investment, travel, popular culture and other interaction form that national boundary become increasingly vague. In addition to Kasongan village that have long developed Pundong also becomes global ethnic earthenware craft artistic product icon in Indonesia. The export activity of the earthenware craft artistic products from Pundong to Australia, Canada, America and Europe indicate that the craft artistic products have good salability in global market. The introduction of the earthenware artistic products of Indonesia that have ethnicity nuance establishes international relationship in the form of tourist travel, business, and so on. In many cases, the globalization has similar characteristics with internationalization and the two terms may be used interchangeably. Some uses the term globalization related to the decreasing role of a nation or the increasingly vague of national boundary.

Global change is inseparable of global cultural transformation. David Held suggests that globalization relates to global trade, global market, global production network, and global culture. The description relates to anything related to globalization that gives impact on local culture that it is necessary to anticipate the transformation using regulation through good network (David Held, 1999). Ceramic artistic products are produced in Pundong in response to the global trade and information technology and hence they can be accessed 
globally even by competitors who produce similar products. It is also possible that the products are brought by business men to other countries and reproduced in the countries. Consequently, adoption and mutual influence not only take place at national level but also at international level. The mutual influence not only takes place as a result of the presence information globalization but also as a result of international export-import trade among countries such as China, Vietnam, India, Thailand, Philippine and others. Buying samples and bringing them home, buyers may also reproduce them and sell them at lower price. It results in rapidly growing mutual influence. Such trading pattern results in easy counterfeiting of a product produced in an area because of the "close" interaction so that each areas producing similar products has broader characteristics. Thus, it is highly possible not to consider the products as of Indonesian characteristics but Asian or Southeast Asian characteristics as found in the distinction of Asian and European Arts. Even, the products have lost the original characteristics of their place of origin. It is a result of the globalization that puts the emphasis on the efficiency and effectiveness.

Strategies are required in developing globally oriented craft arts, especially in the originality of new inventions that are able to substitute the existing inventions. New design products must be created to diversify them in satisfying changing market demand. Diffusion is the creation of new culture by mixing new culture with old one. Creative craftsmen may improve their creativity by combining new culture with old one. Therefore, emerging design trend in Western countries differs from that in Asia. The trend will determine product salability. Subsequently, reinterpretation is a cultural transformation as a result of cultural modification of the prevailing era. It results in the repro antique handicraft representing Greek earthenware or porcelain jug and vase such as amphora, panathenaic amphora, calyx krater, volute krater, and lekythos (David G. Wilkins, 1997: 89). The earthenware was usually used to keep wine, olive oil, money and water. The shapes have been reproduced with different function. Thus, the reinterpretation is reproducing old products many people have forgotten.

The change in global trade is the causal factor of the craftsmen in Pundong to follow international trading pattern. It is also manifested in their daily life pattern in doing their activities of producing earthenware, socialization and business competition. There is a paradox in their life in which in one hand their relationship seems to be harmonious, while they compete in their business in other hand.

Subsequently, considering the aforementioned description, the study aims at: (1) investigating the impact of globalization and cultural transformation on the behavior of Pundong people, (2) finding out the impact of globalization and cultural transformation on the household life of Pundong people, (3) finding out the impact of globalization and cultural transformation on the education of Pundong people, (4) finding out the impact of globalization and cultural transformation on the traditional order of Pundong people.

The uses of the study are: (1) to contribute thoughts to similar studies, whic are on the significant impact of globalization and cultural transformation on the villages with home industry outside Pundong village, (2) to contribute thoughts to the study of the phenomena of the intereference of external factors in the industrial villages as Pundong, and so on.

\section{Globalization And Social And Cultural Transformation}

Computer and telecommunication service are the media to access global world, especially in smallscale company without long and winding bureaucracy. Deregulation and globalization have provided smallscale businesses with opportunity to access capital. All of consumers coming from all over the world may be accessed through communication technology displaying selected products and life style to seize market and market niche. However, creativity is prone to counterfeiting in a global information era and copyright breach and so on. So, innovation plays an important role to win the competition that new entrepreneurs emerge (Naisbitt, 1994: 4-9). In the present era creativity plays an important role in operating their business in various areas, including earthenware craft arts. Commercial right, brand name, design right, patent right, and so on are important to consider, but creativity in the area of craft arts is highly fluctuating and hence the effort to obtain intellectual right becomes irrelevant considering the rapid change.

The development of Pundong earthenware craft arts is inseparable of both external and internal influences. Alvin Boskoff's theory in his work Recent Theories of Social Change is worth to consider. It describes social and cultural transformation of a society. Cultural transformation is not only caused by external factors though the factors dominate of the transformation, but also by internal factor (Alvin Boskoff, 1964: 140).

Boskoff's opinion is corroborated by R. M. Soedarsono in his book Seni Pertunjukan Indonesia di Era Globalisasi (2003), especially in Chapter I "The Development of Performance Art in Indonesia from an Era to Another", suggesting that the change is observed in external and internal factors. The strong external influence comes from Hindu, Islam and Western. The external factors form the present Indonesian performance arts (R. M. Soedarsono, 2002: 2). Though theory is applied to examine the change in the performance art, the mutual influence causes the change in the study of other areas of arts, including earthenware craft arts. Essentially, the external factors of the social transformation of Pundong people are very significant, but when it is not supported 
by the presence of local genius, there will not be any significant artistic works. Thus, Boskoff's and Soedarsono's theory of change not only puts the emphasis on the external factor able to present earthenware art products that penetrate global market, while it also get responses from creative artists with strong spirit to consider global market.

There are some creative craftsmen in Pundong village and they represent the ones who present new shapes of earthenware that fit international market. The adaptation begins with each of the craftsmen of those coming to Pundong village. The interaction between visitors and the craftsmen in the earthenware arts is business relationship of earthenware crafts.Other relationship takes place in government program that aims at improving the prosperity of the craftsmen and their capability to develop their business. The presence of other private institutions and non-government organizations plays an important role in the transformation and the development of Pundong people.

The presence of foreign people who influence the cultural dynamics of the earthenware artistic products of Pundong, it is considered to be relevant in term of anthropological theory described by Kodiran suggesting that cultural dynamic mechanism resulting from diffusion, acculturation and renewal (Kodiran, 2000: 4). The creation of the earthenware craft arts in Pundong that penetrates global market results from the cultural dynamics. The diffusion is one of the cultural distribution elements from one place to another. Usually, the distribution is caused by the immigration of people to a place. Their culture diffuses into the culture of the people of the place of migration destination. The inter-individual encounter results in mutual learning and understanding of their respective cultures, including trade relationship. In this case, traders come into an area and their culture diffuses with the culture of the welcoming people.

The changing earthenware craft arts of Pundong are also guided by the cultural institutions of the surrounding people. Concerning with the description, cultural sosiological theory suggested by Raymon Williams in his book Culture (1981: 17-19) is relevant enough to examine the topic. Williams describes that there are three important and useful components in cultural sociology. They are: 1. cultural institution, 2. cultural content, and 3. cultural effect. It is corroborated by Kuntowijoyo (1987: 5) suggesting that cultural institution deals with who produces cultural products and who are their patronages and also who controls and how the control is used. Meanwhile, the cultural content deals with what are the resulting products and the cultural effect deals with what are the expected consequences of the cultural process. The concepts described above are considered to be relevant to find out who deserve credit in motivating the craftsmen of Pundong to be more creative to anticipate future development.

The earthenware craftsmen of Pundong are very enthusiastic in facing global era and hence it is necessary to refer to the book Global Paradox written by John Naisbitt. Concerning with the economic theory of global world, John Naisbitt describes that the change in trade and industry is indicated by the increasingly rapid global economic development that empowers small players. The earthenware craft arts of Pundong included in the micro industry center has global capability and indicated by the big number of small players that relate to each other so that the small scale economic power moves globally. Therefore, the study of the small-scale entrepreneurs is incorporated with the study of how big bang of the global economy takes place in the global economic development.

Big companies decentralize and rearrange themselves as entrepreneur network. It is now the smallscale companies that are able to survive. Business activity network in the earthenware craft arts center of Pundong has naturally developed in the cooperation between the craftsmen when order fluctuation takes place. The form of the cooperation of the "big" companies and down lines and suppliers takes place in the center of the earthenware craft arts of Pundong. It also takes place in other industrial centers of the craft arts. Naisbitt exemplifies that China reached 10 percent of annual sale in 2006 and it was dominated by small-scale entrepreneurs. They have endurance in their simpler and labor intensive working pattern. Thus, the implementation pattern of the trade in the form of export is controlled by small-scale business units.

\section{The Social Condition And Kinship System}

The social condition of rural society indicates that there is social-economic difference referring to the land ownership status, descendant and social position that are used as the basis of social stratification. Based on the consideration, Javanese classifies social strata into five, which are 1. the immigrants with no land ownership and no house and hence they are referred to as tenants (mondhok or glongsor), 2. the villagers with no land ownership and only have house and yard (lindhung), 3. those who works on other's land (kuli), 4. those coming from the elder head circle (tiang baku), and 5. the members of village government officers (prabot dhusun). Additionally, there is one more stratum considered as separated from other strata, which is santri.

Interest similarity is based on kinship network and real benefit in social life, familiarity, someone's memory. The need of human being for close and warm socialization that give old days warranty is satisfied in extended nuclear family, for example nuclear family of a woman who uxorilocally live in female family, the nuclear family of a man who lives virilocally in male family, or the nuclear family of male and female children 
that settle utrolocally that gives newly married couple to determine the place where they live whether it is the family of the wife or the family of the husband.

The extended nuclear family represents an independent social unit. It means that the social unit manages its own household economy and its property, rears children, and responsible for the socialization and enculturation process its young generation, helps operate agriculture enterprise for subsistent consumption. It is also the case or the cooperation in various other activities for example in organizing various custom or religious ceremonies. The present social, economic and cultural needs are no longer satisfied by households and other institutions such as mutual assistance (sambatan), but it begins to depend on artisans. Therefore, the kinship system fades with the presence of other institutions that influence the behavior of its members, including their jobs. It reflects on the activities of Pundong people with their routine activities in producing ceramic craft arts with characteristic social and cultural life. It is described by Soedarsono in his book Seni Pertunjukan: Perspektif Politik, Sosial, dan Economi. He suggest that the presence of a group or a class in a state will cause the emergence of the arts that fit the taste of the group. Underscoring the opinion, the emergence of ceramic craft arts in Pundong is inseparable of the presence of Kyai Song who was credited as the one that developed the ceramic craft art in Pundong village in the struggle era of Prince Diponegoro. It gave birth to the social stratum of ceramic craft arts and now the ceramic craft arts has developed its global orientation following international development. It is because the change in the interests in the ceramic craft arts for international consumers through export.

In one hand, the global thinking pattern is found the activities of craft business, while in other hand they also respect and comply with the existing custom norms of Pundong. The custom norms are valid for generations and it is normal for them to uphold and to respect the legacy of their predecessors.

From the point of view of social and cultural values of a society, the development of Pundong village is influenced by various factors, including internal factor of the products of the people of Pundong and external factor that changes the people. The change in the social and cultural values in the acculturation process is the causal factor of the development of Pundong village. Acculturation is the blending process of two cultures or more in a mutual influence relationship or selective absorption of foreign culture by the people of Pundong. It is not only related to customs, but also to institutional change, education, self-supporting and mutual assistance. The internal and external factors directly and indirectly influence the ceramic craft art products of Pundong. The factors give mutual influence to each other in the development of the village.

The social life of a society includes the living unit of the local people. As noted by S. P. Gustami that local living unit is established to find out how the people of Pundong as the producers of ceramic craft art products have strong characters. It is because they conserver environment and preserve the ceramic craft art tradition and consider the ceramic arts as their livelihood, while at the same time follow government program.

In the kinship system and condition, especially in the circle of the ceramic craftsmen of Pundong and the surrounding areas there are bilateral principles that connect their kinship through two parties of male and female sides. Both parties follow their respective descending principles. However, not all of their biological descendants can organize joint activities and the bilateral principles in Pundong village and the surrounding areas are classified into concentric principle (i.e., the same origin), by considering the kinship system of limited number of kinship members. The limitation is actually not absolute, but the limitation in the memory of the people causes limited number of generation they are able memorize.

The life of Pundong people is inseparable of the existing custom. However, there are other social institutions in their life. The institutions in the village are an organizational space and the driving motor in the development of the village. The institutions are classified into two, which are public and private sectors. The public institutions include Badan Permusyawarahan Desa (BPD), village consultative assembly, as legislative institution at village level. It includes hamlets (Pedukuhan)and neighborhood association(Rukun Tetangga), administrative unit at the next-to-lowest level a villate (Rukun Warga). Additionally, there is also Lembaga Kesejahteraan Masyarakat Desa (LKMD), a welfare body for rural society that play an important role in improving people prosperity. It covers hamlet area, while the institution related to the ceramic craft arts is found in Unit Pelayanan Teknis (UPT), a technical service unit in Pundong that is established by the Department of Industrial Affairs and Trading. The private institution in Pundong is Koperasi Kerajinan Keramik Pundong (Kopinkra) "Setya Bawana" as a means for the craftsmen to meet and discuss any thing related to their business activities.

Pundong people as the village that produces ceramic craft art products has their own social and cultural living pattern in a social community of ceramic producers. Therefore, the people of Pundong have characteristic imagination and creation of ceramic craft arts with the same spirit.

The people of Pundong are those living together in a village with the characteristics of rural society and the villagers have a good mastery of ceramic production. The characteristic of the villagers may be observed in the condition of Javanese rural societyin general who uphold rural custom of mutual assistance. The opportunity for the rural people to take a part in a democratic decision making is determined not only by the power and 
leadership structure in the decision making, but also by the characteristics of the people and the condition of the region where they live. The cultural background of Pundong people is close to Javanese mysticism (kejawen) and it becomes the basis of their thinking pattern, their action in their daily life activities and in their social life. The social life related to the decision making, the problem solving and individual relationship pattern, the people and the government constantly follow the existing norms. Such relationship is based on the respect for elder people or those with authority in the governmental regulation.

In a transition from agrarian-traditional to industrial-modern society, it is necessary to adapt to material culture as a results of the advancement of knowledge and technology. Maintaining the balance between material culture and adaptive culture represents a middle course in a social and cultural life. In the cultural dialectic process there is actually a bargaining in finding ideal social cultural condition. It reflects on the social life of Pundong people that has increased their economic status, while maintaining its harmonious family life with the existing custom in materializing the ideals of the people of prosperous and equal social life (Gustami and Sunarno, 2001: 67).

\section{A. Behavioral Pattern}

\section{The Condition Of Pundong People And Its Influence On Ceramic Production}

The change in the behavior is manifested in constant the action of an individual of a group of constant pattern and specific in nature, for example, the craftsmen and their home industry, association, or groups that are influenced by globalization. The rapid development of information and communication technology also causes rapid change in the craftsmen society in Pundong both individually and collectively. The negative impact is observed in their daily life. For example, the majority of their time is spent following the schedule of mass media such as television, internet, and other printed media that it quantitatively lowers their productivity. The positive impact is that they can easily access information of the global change related to their production activities of earthenware craft arts. The shift in their behavior resulting from the globalization takes place in many areas such as in the family life of the craftsmen and in their social life. It also indicates the change in the relationship of children and their parents, neighborhood relationship in the environment of the craftsmen among the craftsmen.

Of course, the relationship among families and the relationship with other parties follow different norms. The behavior is formed on the basis of unwritten convention in the tradition of Pundong people. They are aware of what behavior complies with the norms in Pundong such as the respect for elder people, highly regarded people and the people of the same status. Though there is not any difference in casts among Pundong people, such difference customarily still plays an important role. It is especially true when they consider someone to be their prospective son or daughter in law. They still consider what so-called bebet, bebet and bobot. Therefore, their behavior is also determined by custom and tradition. The behavior is identified in the external influence of the visiting tourists who change the life aspect of the earthenware industry center of Pundong that requires the consequence of the globalization era. The culture of the tourist or the buyers coming from all over the world meets the culture of the local people of Pundong. It may be consider that the contact of the different cultures will have influence on all aspects of life of Pundong people. For example, it is observed in the way they speak, the intonation and the style that imitate those of the tourists. It is also observed in the way how they dress, especially the young people of the village in addition to the service for the tourist that follow international standard.

The change in the behavior relates to the social mobility and it is one of the impacts of the rapid information globalization era. Productive craftsmen access information in the globalization stream about the global development of earthenware business. Some teaching staffs of higher education institution work in the earthenware craft industry center of Pundong because of the information of the job vacancy published using information technology. It is highly possible that the advancement in the education and the attraction of the craft business in Pundong increases the social mobility that causes the social and cultural transformation. The phenomena of the social mobility in practice cause the emergence of geographic mobility because of the development of many new entrepreneurs in Pundong and in the surrounding areas. Pundong village is like sugar and wherever there is sugar, there will always be ants (Timbul Raharjo, 2005: 5).

The change in the life style of Pundong craftsmen improves the economy of the local people and in turn it changes their life style that is observed in their appearance with jewelry and new cars. There is an emerging awareness of the craftsmen to deposit their money in banks because of their concern to the increase in criminality as informed in mass media. They feel insecure when they save their money at home. Doing business with buyers they make order through bank transfer and do not use cash money in open account or money order and letter of credit (LC). The payment using the open account poses certain risk to exporters or the craftsmen. Therefore, the payment is made using direct bank transfer to the account of the craftsmen so that they can avoid the risk of the delay in payment or no payment at all. The payment system using the open account is common among the craftsmen because of the complicated document requirement of the payment of the letter of credit 
(Amir, 2005: 84-85). The change in the life style also influence the entrepreneurial behavior because they are exposed to buyers with different social and cultural background such as inviting the buyers to have dinner in establishing business relationship and negotiation with buyers. It also influences how they pick the buyers up in airport and so on.

The development of the earthenware craft art business in Pundong stimulates suspicion among the entrepreneurs. The entrepreneur neighbors are considered to be competitors and they mistrust each other. They worry that the competitors will do plagiarism of the new designs of their products that causes the decrease in price and so on. It influences the cooperation pattern between them. They cooperate with the craftsmen with small-scale business or the lower sub-contract holders. There is not any cooperation among the entrepreneurs of the same business scale, except there is buyer who buys earthenware craft products in a joint buying agreement. The buyer buys the products from some craftsmen and then the products are packed in a container that is referred to as consolidation system. The combination is often made by the buyers for various products from many producers. Consequently, the problem is who serves as the exporters because the export shipment must be signed by exporter, while the exported products come from many craftsmen. It results in the difficulties in arranging export license and permit and the difficulties in taxation. The change also takes place in the producing process of the products that becomes more individually. Even, each of the entrepreneurs work independently and there is not any good communication among them.

The decision making in a family is longer dominated by husbands as family heads, but housewives have bargaining position in the decision making. Actually, women are more careful in operating business. Husbands share their absolute authority with their wives. Wives has got equal position as their husbands in carrier and in other areas of life. Many managers of the earthenware companies in Pundong are female that it is common that female has higher position than male, including her income. Even, many husbands do domestic works, while their wives do their job as breadwinners. Additionally, children also play an important role in family business. It indicates the entrepreneurial mentality of the family. Therefore, the earthenware craftsmen do their job in their family environment.

The work is done along with family members in a home industry, including husbands, housewives, and children. Wives play the role as harmony builder in the family life and also their children. When domestic works and earthenware production are done in a family, housewives must be much busier. They are busy producing earthenware craft products, while serving as housewives. Considering their carefulness and their perseverance, responsibility are on housewives' shoulders. Husbands are consequently on the position of household assistants in accomplishing the tasks related to the production of the earthenware art products. Actually, the change in the role takes place for the purpose of appreciating women's role in doing business. They do not have any problem with gender, but focusing on the development of their business. Finally, it is creativity and skills that play an important role in operating the business. Family dominates the management of business and wives and children play their role in the business.

\section{B. Family Life}

Family is the most important social group in a society. It is the smallest social unit in a society. Nuclear family is a group of individuals who enjoy assistance from their fellow men and security in life. It is a group in which individuals in their childhood are brought up and got their early education (Koentjaraningrat, 1992: 109). For the craftsmen society of Pundong village, family is secure nest and ideal stronghold free of physical and psychological stress.

In daily life of the families of Pundong people social relationship among individuals take place in their family based on the attitude of paying respect to each other. Such attitude is applied in social life along with their neighbors. Paying respect to elder people is observed in the gesture of bowing in front of elder people with low voice. Subsequently, certain terms in their life are used to greet fater, mother, eyang, mas, mbakyu, budhe, pakdhe, and so on. The loss of the attitude of paying respect in family relationship is a result of education in inharmonious family in addition to the globalization and information era in their daily life, including the way they dress, speak, respectfulness, different thinking pattern among young generation and so on. The globalization and the information come to Pundong and sometimes tarnish the attitude of the villagers of paying respect to elder people. Respectfulness in Javanese family has been replaced by Indonesian that is national language. Thus, there are a lot of children of Pundong who do not know respectfulness and do not speak Javanese.

Actually, the social relationship order in the families of Pundong village refers to the cultural system that develops in Javanese society. The cultural value system functions as the guidelines of the behavior of Pundong people. In daily life, the cultural value system is manifested in customs, norms, rules, etiquette, respectfulness, and custom laws. Referring to the cultural value system, people will know what are proper and what are not to do. When Javanese behave against the norms and the cultural value system, they will be considered as ora nJawani, ora nggenah, and murang tata. The bottom line is that the families of the craftsmen 
in Pundong village behave following the existing Javanese norms and parents have inculcated the Javanese values system in their families. However, in their daily life they are exposed to external influences through information media such as television and foreign people coming from various countries. Thus, cultural interactions are unavoidable between the villagers and the foreigners who are of different cultural background. It also influences their family life and also their social life. The family wants their children to be more successful than their parents so that the family education uses language, technology, and other aspects they consider as modern. Consequently, it influences children interaction in school, family and their society. Such social change results in the new generation who are more oriented to modernity than to Javanese value system.

Socio-psychologically, information flow taking place in their life influences various aspects of family psychological life. It also influences the psychological development of young generation. Their behavior is gradually influenced by what are not proper for their psychological development and the existing norms. It is also the case of the influence of television program and cyber space that is supposed to be for adult consumption on children. They are not mature enough to be exposed to adult materials so that they behave against the existing norms. New generation prefers to be preoccupied by computers and smart phone with advance technology to access internet, especially facebook, twitter and other social media. They are absorbed by the cyber space and they forget their real world interaction. It is therefore necessary for parents to anticipate the advancement of the telecommunication technology by explaining a television program and the advantage and the disadvantage of Internet to the children.

Anticipating the negative influence of the technology families with young children in the earthenware craftsmen society of Pundong inculcate strong learning foundation in their young generation such as establishing groups of positive activities and provides their children with toys made of clay. They provide their young children with religious lesson in Al-Quran education informal institution as spiritual foundation. Other activities in preventing the negative impact of the globalization are small group discussion in collective meal of groups of families. It aims at maintaining harmonious relationship among the families who intend to uphold custom and traditional value system in Pundong village.

\section{Education}

The impact of the globalization on the social life of Pundong people is becoming more intense. Pundong people absorb information about global events in their daily life. The earthquake occurrence in 2006 in Yogyakarta could be accessed by people all over the world. It proves that the present information technology has extraordinary influence. It also influences education area. The people of Pundong provide their young children with the education that is inseparable of the knowledge coming from abroad and not only from the parents. They also influence their children. The education influences their mindset because of formal education, family and society.

Formal education in schools is standard education for children from play group to higher education. The presence of the information technology influences students and they become more critical of the existing differences in the mass media. Elementary school students are able to search the material related to their learning material in schools in internet, including anything they want. Such educational impact requires teachers to be more knowledgeable of what happens in cyber space so that they able to keep pace with the knowledge of their students they get independently in internet. Mass media absorbed by the students has both positive and negative impacts. The positive impact is to motivate the students to learn harder. They feel that they are more knowledgeable in illustrating and comparing occurrences they found in the mass media and those they learn at school.

Some of the people of Pundong village have their own internet network. It is observed in the satellite transmitter for internet access around Pundong village or internet network through telephone and modem that are available at low cost. They improve efficiency using internet and emails and also searching information about earthenware in internet. They are online almost 24 hours in their own houses. Thus, external influences goes deeper and they have accessed internet every day. The craftsmen search for new designs in internet in their effort to improve the quality of their earthenware products. Additionally, children also search for other information related to their education.

The negative impact of the globalization on the children of the craftsmen is among other delinquency. It is because the relationship of students and teachers is not vertical, but horizontal. The students are no longer dictated as used to be in New Order era, but teachers and students are more like friends. Otheri influence of the globalizzation is that children becomes more critical and even they underestimate their school assignments. Even, they often ignore the instruction of their teachers and even reprimend their teachers as they found in cinetron or movie television program. The way they dress also changes for example male students use earrings, paint their hair with various colors, wear deliberately torn pants on their knees and many more.

Family education in the craftsmen life whose economic status has improved is influenced by the business activities of parents. The parents often forget the education of their children and their need for 
affection. Some of the parents are absorbed in the activity of producing earthenware products and spoil their children with facilities that are not educative such as car and money. Thus, the children go out of their home to have fun without any appreciation of how hard their parents earn the money. The business of the craftsmen results in their children who are lack of warm affection. Therefore, the children look for compensation using the facilities provided by their parents in negative things. They look for their own way to satisfy their need for affection. The problem is that the children become uncontrolled in consuming raw information, free socialization, criminality, drugs, and so on. Actually, there are several aspects that do not fit the development of the children. For the children who are obedient to their parents, the information technology enables them to be more independent and to have an attitude toward problems. It helps their parents optimize its influence in developing the earthenware products. For example, they can learn internet marketing, search for new design and see the earthenware art products from all over the world as considerations. Not all of the globalization influences is negative. It depends on how the craftsmen filter the influence of the globalization.

Education in a society is a social interaction as found in the community of earthenware craftsmen of Pundong. The communication among them takes place in a forum such as cooperation Lancar Jumangkah Pundong and the meeting of neighborhood association $(R T)$. The groups provide them with communication space in maintaining harmonious social life. They will solve their problems in such meeting, including earthenware crafts artistic design, raw materials, information on assistance and building program by government and so on. Some kinds of informal meeting also provide them with a forum to casually discuss anything appertaining to the earthenware production, including the negative and the positive influence of the globalization. Such informal meeting and discussion often takes place in traditional food stall called angkringan. Insensibly, they discuss about the recent development of their society for example the new information technology and the new assistance, the development of the marketing, the development of infrastructure, and so on. It is often the case that such informal discussion contributes creative idea to implement in social activities. Sharing information enables the villagers to broaden their knowledge, including the information they access through information technology.

\section{Traditional Order}

Cultural values as behavioral and good conduct guidance are manifested in custom laws and respectfulness norms. The behavior and good conduct guidance contains cultural values that must be preserved and even developed as cultural values in Pundong village. The manifestation of the harmonious life among the villagers is the mutual assistance (gotong royong) representing a good will to live a harmonious life of the villagers. The social awareness to help each other in easing other living burden is also observable among the villagers, especially in the custom and social norms in the village. There is a kind of personal mutual assistance in addition to community service. The mutual assistance and the community service are the means to provide those who get calamity or those who are mourning, mishap, and even in the construction of terraced house, disassembling roof tiles or any communal activities that requires quick completion. Such social assistance is usually provided voluntarily and those helped provide their helping neighbors only with meal and drinking water.

The bustle resulting from the development of the earthenware craft art industry does not enable the member of the community to present in the event of mutual assistance (gotong royongi). The activities in operating earthenware business sometimes takes the majority of their time, especially when they get order that must be completed on certain deadline. Therefore, it is common practice for those who do not have time to take a part in the community service to pay others to involve in such event. Another way is to contribute foods such as sugar, snacks, beverage to the community service. The shift in the mutual assistance takes place because of the change in the competition in the international business, the demand of the buyers who are of different social and geographic conditions for quick completion of the order and the timeliness in delivering the products have made them under constant stress in the global era.

The impact of the business pattern is observed in the improvement of their economy because they begin to consider that time is money. The globalization era informs many practical life styles and it results in the fading tradition of the mutual assistance and the community service in Pundong though they are occasionally still involved in the social traditional events for the purpose of preserving the tradition. The mutual assistance before 1980s was organized in a day and not limited on holiday only. However, to day the mutual assistance event is organized on holiday only, especially on Sunday that lasts for only two to three hours. When the mutual assistance is organized to build public facilities such as security posts, graveyard fence and so on they agree to contribute some money to pay some artisan workers to complete the job. So, the influence of the globalization era in their living order, especially in the tradition of mutual assistance, is observed in the fading mutual assistance tradition and it replaced by pain artisan workers. Such condition will continue to the point that the cohesiveness of the villagers also fades and it is replaced by the artisan workers paid collectively by those who are supposed to do the mutual assistance because they are busy operating their earthenware business. 
The expression of cohesiveness and harmony is spontaneously observed when one of the villagers experiences calamity or is mourning. It is announced using loudspeakers in mosques and neighbors come voluntarily to do mutual assistance and inform rois to take care of the corpse till the burial. The ceremony is referred to as layatan, which is burial ceremony. The part of the ceremony is called pamit jenazah, consisting of speech by village officer of the rois telling short story of the deceased. In the evening after the burial of the deceased collective pray (tahlilan) is organized for the purpose that the soul of the deceased get proper place beside God and all of his or her sins are forgiven. The mourning family and relatives of the deceased who died on the Javanese days Selada Klion and Jumat Kliwon, must watch over the graveyard for 40 days. It is because there is a belief among Pundong villagers and Javanese people in general that the head of the buried body will be stolen by those who want to be rich using magic that uses the head to manipulate the soul of the deceased to give the stealer richness. Forty days after the burial ritual meal and collective pray is organized in the traditional ceremony of tahlilan and kenduri. Such ceremony is also organized in 100 days, 360 days and 1000 days after the burial that is followed by placement of gravestone (ngijing).

The participation of the villagers takes place spontaneously though they expect that someday when the time comes they will be treated the same way. It represents a reciprocity principle among the villagers of Pundong. Those who never take a part in such mutual assistance and community service will be left alone when they are in need for help. Another expression of the cohesiveness and harmony is observed in building a house, the construction of neighborhood street, construction of furnace, building house of prayers and so on. Such cohesiveness and harmony relate to the sense of needing each other among the villagers. It is not the case of those who do not involved in the mutual assistance and community service. Such individuals will surely be ostracized and will not get other's help in time they need help.

The manifestation of the cohesiveness and the villagers are observed in the organization of the ceremony of the gratitude to God, especially in the events of the ritual of passage from cradle to the grave, including birth, circumcision, marriage and death. So, small ceremony such as birth ceremony does not require the presence of a lot of neighbors, but big ceremony such as marriage ceremony requires organizing board to organize the marriage ceremony. The villagers must tolerate the temporarily closing of certain street when a community event is organized and the street becomes only to one way street. Even, when there are foreigners visiting the village, they face difficulties in adapting to the local tradition of Pundong village. However, there are those who enjoy the ceremonies with art performances such as ketoprak, campursari and puppet shadow play. Those who are not able to organize such ceremony prefer simpler ceremony. It is logic preference because of the advancement of information and communication technology and they must be thrifty.

The information technology influences the social life of local people. Information can support and hamper decision making process. Thus, globalization era has the power to develop and to destroy something. It depends on the ability of the users in making a proportional use of the technology, especially for the development of the earthenware craft arts that the earthenware craft art business becomes more productive. Considering that the majority of the earthenware craft arts of Pundong are consumed by global consumers, the globalization era is not considered as obstacles, but as the bridging means in the negotiation with international buyers.

\section{A. Conclusion}

\section{Conclusion And Recommendation}

1. The trade of earthenware craft arts has formed the character of the craftsmen of Pundong as entrepreneurs of modern business who are able to adpt to global culture. The earthenware craftsmen of Pundong think effectively and efficiently, including in the transformation of the traditional custom of mutual assistance (gotong royong) and of the social interaction pattern of their society. Globalization becomes normal thing for the villagers of Pundong and they are able to interact with consumers coming from Europe so that they use the service pattern of international standard such as language, dinner, accommodation and so on.

2. The community of the earthenware craftsmen of Pundong is more open and able to adapt to foreign culture such as service pattern using technology and also trade rules in globalization era such as export document, product quality and delivery timeliness. Web-based marketing is also common among them. Communication between producers and consumers of the earthenware craft arts from all over the world is not problem for them. They are able to make transaction by sending product picture, price list, invoice and other export document that they are completed in the matter of minutes.

3. There is internal influence on the earthenware craft arts of Pundong as innovators who play active role in developing materials, production technology and design. Additionally, there is also external influence, including the involvement of designers, educators, and cultural observers, chief officers of both public and private institutions and domestic and international business actors. 


\section{B. Recommendations}

1. It is necessary to make improvement step, synergy among various public and private parties, government, and other parties concerning with the earthenware craft arts of Pundong, especially the incoming negative influence.

2. It is necessary for the government to materialize the idea of establishing a museum for earthenware collection. The museum is important to anticipate the globalization with its business considerations that ignore the aesthetic aspects of the authentic and original earthenware craft arts of Pundong.

Books:

\section{References}

[1] Boskoff, Alvin, "Recent Theories of Social Change" in Werner J. Cahman dan Alvin Boskoff. Sociology and History: Theory and Research. London: The Free Press of Glencoe, 1964.

[2] Held, David, Anthony McGrew, David Goldblatt, and Jonathan Perraton. Global Transformations. California: Stanford University Press, 1999.

[3] Ketut Suwondo, Civil Society: Di Aras Lokal, Salatiga: Pustaka Percik, 2005.

[4] Koentjaraningrat. Kebudayaan, Mentalitas, dan Pembangunan. Jakarta: Gramedia, 1974.

[5] .ed. Masyarakat Desa di Indonesia. Jakarta: Lembaga Penerbit Fakultas Ekonomi Universitas Indonesia, 1984

[6] Kebudayaan Jawa. Jakarta: Balai Pustaka, 1984

[7] Kuntowijoyo. Budaya dan Masyarakat. Yogyakarta: Tiara Wacana, 1987.

[8] . Metodologi Sejarah. Yogyakarta: Tiara Wacana, 1994.

[9] Peursen, C.A. van, Strategi Kebudayaan, Yogyakarta: Kanisius, 1988.

[10] M.S., Amir. Ekspor-Impor: Teori dan Penerapannya. Jakarta: Penerbit PPM, 2005.

[11] Naisbitt, John. Global Paradox. Terjemahan: Budijanto. Jakarta: Binarupa Aksara, 1994

[12] Raharjo, Timbul.Teko dalam Perspektif Seni Gerabah. Yogyakarta: Tonil Press, 2001.

[13] Soedarsono, R.M.,Seni Pertunjukan Indonesia: Perspektif Politik, Sosial, dan Ekonomi Yogyakarta: Gadjah Mada University Press, 2003.

[14] . "Industri Pariwisata: Sebuah Tantangan dan Harapan bagi Negara Berkembang" dalam Tjok Rai Sudharta, ed. Kebudayaan dan Kepribadian Bangsa. Denpasar: Upadasastra, 1993.

[15] . Seni Pertunjukan Indonesia dan Pariwisata. Bandung: Masyarakat Seni Pertunjukan Indonesia, 1999.

[17] Seni Pertunjukan Indonesia di Era Globalisasi. Cetakan Ketiga. Yogyakarta: Gadjah Mada University Press, 2002 .

[18] Soemodidjojo, Raden. Kitab Primbon Betaljemur Adammakna. Terjemahan Ir. Wibatsu Harianto. Yogyakarta: CV Buana Raya, 1994.

[19] Wilkins, David G., Bernard Schultz, and Katheryn M. Linduff, Art Past, Art Present. Third Edition. New York: Harry N. Abrams, Inc., 1997.

Theses:

[20] Dwi Budiwiwaramulja, “Gerabah Pundong” (Tesis sebagai syarat untuk mencapai derajat Sarjana S-2 pada Program Magister Seni Rupa dan Desain, Institut Teknologi Bandung, 1988.

[21] Murniatmo, Gatut, Tashadi, Hisbaron Muryantoro, Taryati, dan Suyami. Dampak Pengembangan Pariwisata terhadap Kehidupan Sosial-Budaya Daerah Istimewa Yogyakarta. Yogyakarta: Departemen Pendidikan dan Kebudayaan, Direktorat Jenderal Kebudayaan, Direktorat Sejarah dan Nilai-nilai Tradisional, Proyek Penelitian, Pengkajian dan Pembinaan Nilai-nilai Budaya, $1993 / 1994$.

Paper:

[22] Kodiran. Perkembangan Kebudayaan dan Implikasinya terhadap Perubahan Sosial di Indonesia. Pidato Pengukuhan Jabatan Guru Besar pada Fakultas Sastra, Universitas Gadjah Mada, 3 Juni 2000.

[23] Raharjo, Timbul. Teknik Pengembangan Desain". Makalah yang Disajikan dalam rangka Pembinaan Teknis dan Manajemen Industri Kerajinan Gerabah di Srihardono, Pundong, Bantul, Yogyakarta, pada 1 Desember 1999.

[24] .Usaha Seni Kerajinan : Posisi dan Potensi Masa Kini". Makalah Seminar Disajikan dalam Diskusi pada Acara Beber Seni di Benteng Vredenberg Yogyakarta, pada 23 Desember 2005.

[25] .Awas Pelan-pelan Banyak Pemuda". Makalah Ceramah Kepemudaan, Komite Nasional Pemuda Indonesia (KNPI) di Taman Budaya Yogyakarta, 2 Januari 2006.

. "Gempa Bumi 27 Mei 2006 di Pundong Bantul". Laporan Kerugian Pengusaha/Pengrajin pada Sentra Seni

[26] Kerajinan Gerabah Pundong Akibat Gempa Bumi di Yogyakarta pada 27 Mei 2006.

. "Pundong bukanlah Kosongan". Makalah disampaikan pada Pola Pembinaan Desa Pundong yang Dijadikan Model

[27] Pembinaan untuk Pengrajin Anyam Bambu di Sleman Yogyakarta. Diselenggarakan oleh Universitas Islam Indonesia, 2008.

[28] Soedarsono, R.M. "Peranan Seni-Budaya dalam Sejarah Kehidupan Manusia: Kontinuitas dan Perubahannya". Pidato Pengukuhan sebagai Guru Besar pada Fakultas Sastra Universitas Gadjah Mada, Yogyakarta, 1985. 